\title{
Derive a New Equation to Find the Total Dissolved Salts in Soil by Applying the Hydrometer Test
}

\author{
Maysam Th. Al-Hadidy ${ }^{1}$
}

\begin{abstract}
:
The adding of water to the soil dissolved the salts (that could be soluble) by breaking its down into ions. These ions attract with the water molecules which in turn bind them tightly and that will increase the amount of matter per volume (density). So the (soil solution) is denser than the distilled water and this because of the dissolved salt. This is the point to start from it in this research to find the total dissolved salts.

The hydrometer test In usual used to find the curve of the particle size distribution for the soil, in this research a new equation derived to find the total dissolved salts by applying the hydrometer test.

This derivation built on the base of that the dissolved salts of the soil could be calculated from finding the density of the (soil solution) at the end of the sedimentation of the hydrometer test. In this paper this derived equation is present with a proposed procedure to find the total dissolved salts, and it give a very good result where the correlation factor equal to(0.988) and the root square equal to(0.9755).

By applying the proposed procedure, the dissolved salts test could be easier, and this because it applied indirectly during applying the ordinary hydrometer test and that will make the test of the total dissolved salts faster and cheaper.
\end{abstract}

Keywords: hydrometer,dilution, total dissolved salts, saline density, gravimetric method,deflocculating agent

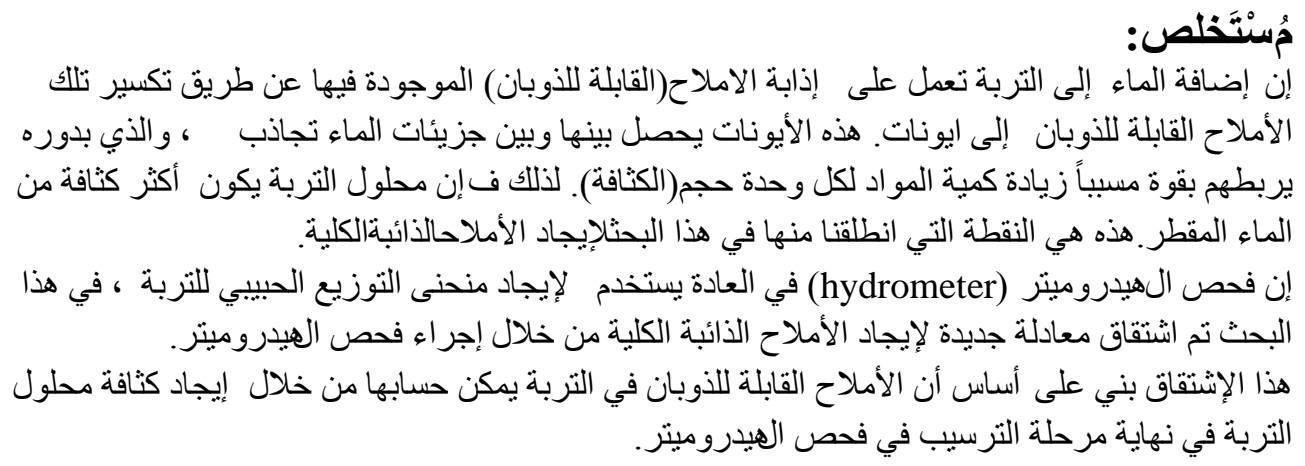

\footnotetext{
${ }^{1}$ University of Baghdad, College of Engineering, Civil Eng. Dept.Iraq.
}

Email: maythamer@yahoo.com

E - 21 


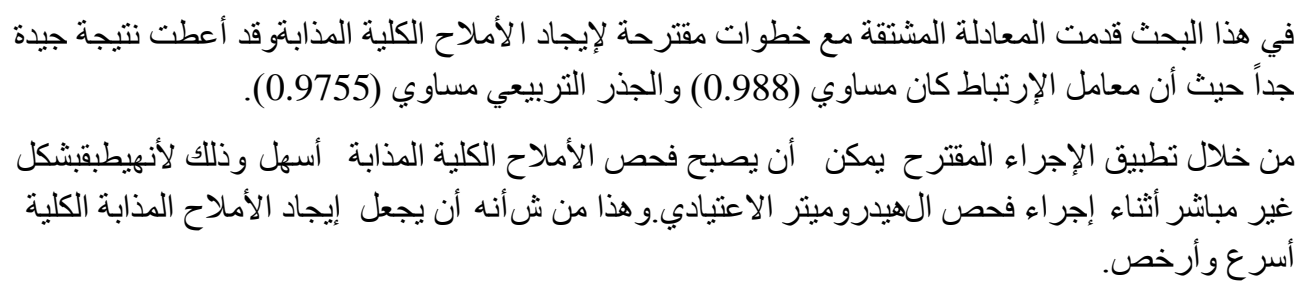

\section{Introduction:}

In many regions of the world a large areas are covered with soils containing water-soluble salts. These saline soil conditions tend to prevail in many regions of the Middle East countries (Al-Amoudi and Abduljauwad, 1995; Bilsel, 2004). Construction on these soils is quite problematic especially in regions of dry and hot climates due to the severe effect of salt corrosion on structural elements(Rongzhen et al., 2006) and due to its high collapse potential and low-bearing strength(Al-Amoudi, 2001).

The minerals of soils are predominantly formed by atoms of oxygen, silicon, hydrogen, and aluminum, organized in various crystalline forms. These elements along with calcium, sodium, potassium, magnesium, and carbon constitute over 99 per cent of the solid mass of soils.(Mitchell and Soga, 2005), and all natural waters contain soluble salts. Water in the soil also contains soluble salts (sometimes called free or nonattached salts).(ElSwaify, 2000).

However, it is worth remembering that various types of salts might be present within the soil, but the most frequent and significantly soluble types are listed in Table 1. These salts have high solubility relative to the carbonates (Osama et al., 2008).

\section{Densities}

Density should be considered to be a function of pressure, temperature of the fluid and concentration of dissolved solids:

$\rho=f(p, T, S)$

Where:

$\rho=$ density $\left(\mathrm{kg} / \mathrm{m}^{3}\right)$

$p=$ pressure $\left(M L^{-1} T^{-2}\right)$,

$T=$ temperature $\left({ }^{\circ} \mathrm{C}\right)$, 
مجلة العلوم الهندسية - العدد السابع - ديسمبر 2014

$S=$ salinity 1 or total dissolved solids (TDS) $(m g / l)$.

Table (1): Salts encountered in soils with their densities and solubility, (Weast 1974).After Osama et al., (2008).

\begin{tabular}{|c|c|c|c|c|c|}
\hline Salt formula & Salt name & $\begin{array}{l}\text { Molecular } \\
\text { weight, } M \text {, } \\
\mathrm{g} / \mathrm{mol}\end{array}$ & $\begin{array}{l}\text { Specific } \\
\text { gravity }\end{array}$ & $\begin{array}{l}\text { Solubility at } \\
20^{\circ} \mathrm{C} \text {, as } \\
A \%\end{array}$ & $\begin{array}{l}\text { Solubility at } \\
25^{\circ} \mathrm{C} \text {, as } \\
A \%\end{array}$ \\
\hline $\mathrm{CaCl}_{2} \cdot 2 \mathrm{H}_{2} \mathrm{O}$ & $\ldots$ & 147.02 & 0.84 & 42.7 & 52.1 \\
\hline $\mathrm{CaCl}_{2} .6 \mathrm{H}_{2} \mathrm{O}$ & & 219.08 & 1.71 & $\cdots$ & $\ldots$ \\
\hline $\mathrm{CaSO}_{4}$ & Anhydrite & 136.14 & 2.96 & $\ldots$ & $\ldots$ \\
\hline $\mathrm{CaSO}_{4} \cdot 0.5 \mathrm{H}_{2} \mathrm{O}$ & Bassanite & 145.15 & 2.74 & $\ldots$ & $\cdots$ \\
\hline $\mathrm{CaSO}_{4} \cdot 2 \mathrm{H}_{2} \mathrm{O}$ & Gypsum & 172.16 & 2.32 & 0.2014 & 0.2082 \\
\hline $\mathrm{MgCl}_{2}$ & & 95.22 & 2.32 & & \\
\hline $\mathrm{MgCl}_{2} \cdot 6 \mathrm{H}_{2} \mathrm{O}$ & Bischofite & 203.31 & 1.57 & 35.3 & 35.5 \\
\hline $\mathrm{MgSO}_{4}$ & & 120.37 & 2.66 & $\ldots$ & $\ldots$ \\
\hline $\mathrm{MgSO}_{4} \cdot \mathrm{H}_{2} \mathrm{O}$ & Kieserite & 138.39 & 2.45 & $\ldots$ & $\ldots$ \\
\hline $\mathrm{MgSO}_{4} .4 \mathrm{H}_{2} \mathrm{O}$ & Leonhardtite & 202.45 & 2.01 & $\ldots$ & $\ldots$ \\
\hline $\mathrm{MgSO}_{4} 6 \mathrm{H}_{2} \mathrm{O}$ & & 238.47 & 1.72 & & \\
\hline $\mathrm{MgSO}_{4} .7 \mathrm{H}_{2} \mathrm{O}$ & Epsomite & 246.48 & 1.68 & 25.2 & 26.7 \\
\hline $\mathrm{KCl}$ & Sylvite & 74.55 & 1.99 & 25.5 & 26.4 \\
\hline $\mathrm{K}_{2} \mathrm{SO}_{4}$ & Arcanite & 174.27 & 2.66 & 10.0 & 10.75 \\
\hline $\mathrm{NaCl}$ & Halite & 58.44 & 2.16 & 26.38 & 26.43 \\
\hline $\mathrm{Na}_{2} \mathrm{SO}_{4}$ & Thenardite & 142.04 & 2.67 & $\ldots$ & $\ldots$ \\
\hline $\mathrm{Na}_{2} \mathrm{SO}_{4} \cdot 10 \mathrm{H}_{2} \mathrm{O}$ & Mirabilite & 322.14 & 1.46 & 15.97 & 21.88 \\
\hline
\end{tabular}

The influence of pressure can be neglected under the given circumstances for most hydro geologic systems. Furthermore, the influence of temperature on density is of minor importance with respect to the influence of dissolved solids concentration within many hydro geologic systems (Gualbert, 2001).

\section{Hydrometer Testing:}

The hydrometer method was originally proposed in 1926 by Prof. Bouyoucos of MichiganAgriculturalCollege, and later modified by Casagrande(1931). This method depends upon variations in the density of a soil suspension contained in a $1000 \mathrm{~mL}$ graduated cylinder. The density of the suspension is measured with a hydrometer at determined time intervals; then the coarsest diameter of particles in suspension at a given time and the percentage of particles finer than that coarsest (suspended) diameter are computed.

The change in specific gravity is related to the fall velocities of specific particle sizes in the liquid. This part of the test is commonly referred to as a hydrometer analysis (Zhou, 2006).

The hydrometer method is based on the change of density of a soil and water suspension upon the settling of the soil particles. Stokes' Law is used to predict the

$$
\text { E }-23
$$


settling times for various sized particles. Stokes' law states that the rate which particles fall in a viscous medium (water) is governed by the radius of the particles and the force due to gravity (Bouyoucos, 1962).

Use of the hydrometer in establishing extremely accurate clay measurements is accepted as the ultimate gauge by soil scientists. Use of the hydrometer by novices is possible and practical. Much practice is necessary and instructions are carefully described in several of the technical books. (Howard, 1981)

Because of the strong influence of electro-chemical forces on their behavior, colloidal sized particles may remain in suspension indefinitely (particles with sizes from 10-3 mm to 10-6 mm are termed "colloidal.") Sample grain size distribution curves are shown in Figure (1). The nomenclature associated with various grain sizes (cobble, gravel, sand, silt or clay) is also shown in Figure (1). Particles having sizes larger than the No. 200 sieve $(0.075 \mathrm{~mm})$ are termed "coarse-grained" while those with sizes finer than the No. 200 sieve are termed "fine-grained." The results of the sieve and hydrometer tests are represented graphically on a grain size distribution curve or gradation curve. As shown in Figure (1), an arithmetic scale is used on the ordinate (Y-axis) to plot the percent finer by weight and a logarithmic scale is used on the abscissa (X-axis) for plotting particle(grain) size, which is typically expressed in millimeters(Zhou, 2006).

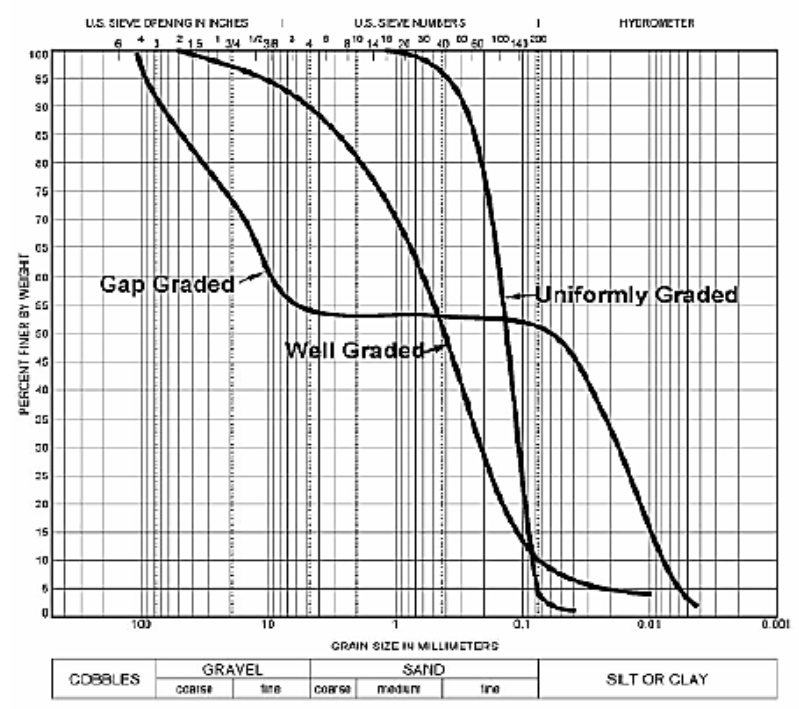

Fig. (1): Sample grain size distribution curves. After (Zhou, 2006)

$$
\text { E - } 24
$$




\section{Deflocculating Agent (Dispersion):}

Individual soil particles must be separated from each other, and kept separated during the determination in order to correctly measure particle size distribution. Since aggregates of solid particles are usually held together by some kind of binding agent, it is first necessary to remove these substances, or at least render them ineffective. Once the soil aggregates are separated into individual particles, they are described as dispersed particles.(Bashour and Sayegh, 2007)

A deflocculating agent can either act as a protective colloid on the soil particle or alter the electrical charge on the particle to prevent the formation of soil flocs. Two commonly used deflocculates are water glass(sodium silicate) and daxad no. 23(polymerized sodium salts of substituted benzoid alkyl sulfonic acid), made by the dewey and almy chemical company of Cambridge, mass. The easiest way to select the best deflocculant and the amount to use for a given soil is by trial. Two cc of a freshly prepared $10 \%$ solution of daxad no. 23 has been found satisfactory for many types of clay; likewise, one -half to one cc of $40^{\circ}$ baumé sodium silicate has been found satisfactory for many types of clay. Sodium pyrophosphate has also been used successfully (Hofmann, 1942), after (lamb, 1951).

Dispersion is achieved by chemical and mechanical means.Sodiumhexametaphosphate is an effective chemical dispersing agent for two reasons:

1. The sodium monovalent cation replaces the usual polyvalent cations adsorbed on soils, thereby breaking interparticle linkages. The polyvalent cations are also reduced in activity as a result of reaction with the phosphorus and consequent precipitation.

2. The adsorbed sodium cations raise the electronegativity of colloids until these particles repel each other and remain dispersed. After the binding agents are removed, aggregates breakdown is further facilitated by mechanical stirring. The mixture of dispersed soil particles in water is called a soil suspension.(Bashour and Sayegh, 2007).

Pug soils require soaking overnight with the calgon alone, and after that possibly also pounding with a pestle for dispersion of aggregates before water is added. (Standard Specification for Urban Infrastructure Works, 2002) 
In this research in all samples tested or compared with the deflocculating agent used was (sodium hexametaphosphate, $\left(\mathrm{NaPO}_{3}\right)_{6}$ with a $4 \%$ solution. And from this solution $\left(125 \mathrm{~cm}^{3}\right)$ mixed with each sample.

\section{Measuring and expressing salinity:}

The concentration of total dissolved salts (TDS) may be determined in many ways, but it is commonly done either by separating and weighing the salts or measuring the electrical conductivity of the soil solution. (Swaify et al., 1983)

\section{Direct gravimetric method.}

A specified volume of an aqueous solution is dried, and the salts contained in it are weighed and expressed as milligrams per liter $(\mathrm{mg} / \mathrm{L}$, equivalent to parts per million, ppm) or as grains per gallon(gpg); (1 gpg = $17.1 \mathrm{ppm})$.

\section{Electrical conductivity:}

Inorganic salts are electrolytes that, in aqueous solutions, are capable of conducting an electric current. The higher the salt concentration, the higher the electrical conductivity (EC).Such measurements are made by specially designed conductivity meters and sensors, and they can be taken either in water or directly in the soil (insitu).

\section{Dilution effects:}

When water is added to a soil to facilitate extraction, slightly soluble salts such as $\mathrm{CaCO} 3$ and gypsum will dissolve if they are present (Reitemeier, 1946). Certain minerals that occur widely in soils dissolve or decompose when exposed to salt solutions (Chapman and Kelley, 1930), but normally these minerals are not abundant enough to merit special consideration.

From the foregoing it may be summarized that as a soil-water mixture is made more and more dilute, the concentrations of dissolved substances tend to deviate further and further from those prevalent under field conditions. Consequently, it has been found desirable to limit the addition of water to soil samples to the minimum amount compatible with the extraction of sufficient soil solution for analysis. This has led to the great popularity of the saturated paste extractions suggested by workers at the U. S. Salinity Laboratory (United States Salinity Laboratory Staff, 1954).after (Kenneth, 1967)

In a study of 1:10 soil-water extracts of a Miami soil, Andersonetet al. (1942) found that the dissolved solids increased from 600 parts per million after one-day contact of soil and water to 3,600 parts per million after 23 days of contact. An 
extract containing 0.25 grams thymol per liter of water had corresponding values of 600 parts per million and 2,250 parts per million. They postulated the latter value was lower because of the partially antiseptic conditions introduced by the thymol.

The increase in soluble material brought about on long standing appeared to be due largely to biological activity. It may also be due in part to the slow solubility of some of the compounds present, and possibly to hydrolytic activity (Andersonetet al., 1942). Reitemeier(1946) also found that the CO2 produced by microbial activity caused an increase in the dissolved calcium concentration.

\section{The derive procedure:}

In this research attempt made to derive an equation to find the total dissolved salts in soil as follow:

This principle is true for all solutions as well: the more dissolved solutes, the denser the solution.

The final point of the distribution curve almost represents the salt particle. From this the derivation is start to find the total dissolved salts in soil sample as bellow:

The final reading of the hydrometer $=r$

To find this $r$ there are two prangs, the first one from the percent finer and the second from the final diameter, any one of them could reach to the result which represent the total dissolved salts.

Starting now with the first prang as follow:

$\mathrm{r}=\frac{\left[\frac{\left(N_{\text {final }} / N_{\text {sieve no 200 }}\right) \times 100}{\left.\left(\frac{G_{S}}{G_{S}-1}\right) \times\left(\frac{V_{\text {cylinder }}}{w_{\text {soilin used h ydrometer }}}\right) \times\left(\frac{\left.\gamma_{w @ 20^{\circ C}}\right)}{10}\right)\right]}\right.}{1000}+1$

(2)The $\quad V_{\text {cylinder }}=1000 \mathrm{~cm}^{3} \quad, \quad w_{\text {soilin } u \text { sedh } y \text { drometer }}=50 \quad \mathrm{gm}$,

$\gamma_{w @ 20^{\circ} \mathrm{C}=}=0.9982 \mathrm{gm} / \mathrm{cm}^{3} \quad$ by simplifying equation (1), equation 2 will be as

follow: 


$$
r=\frac{\left[50.09 \times \frac{\left(N_{\text {final }} / N_{\text {sieve no 200 }}\right)}{\left(\frac{G_{S}}{G_{S}-1}\right)}\right]}{1000}+1
$$

This value could be taken or the value of $r$ could be found from the second prang as below:

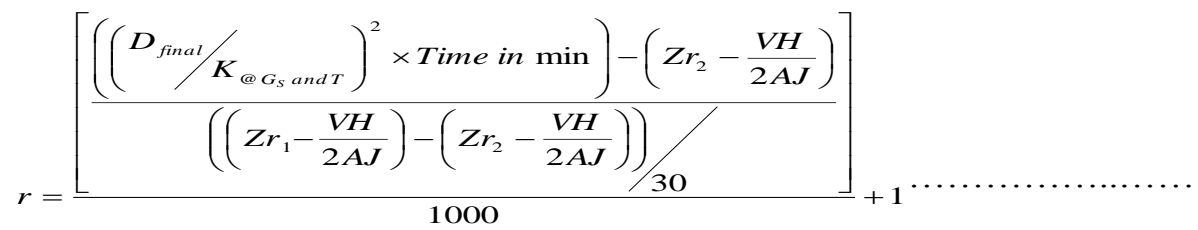

$K$ could be found from Figure(2), $Z_{r 1}$ and $Z_{r 2}$ found from hydrometer dimension as shown in Figure(3) and(VH/AJ) could found as shown in Figure(4). 


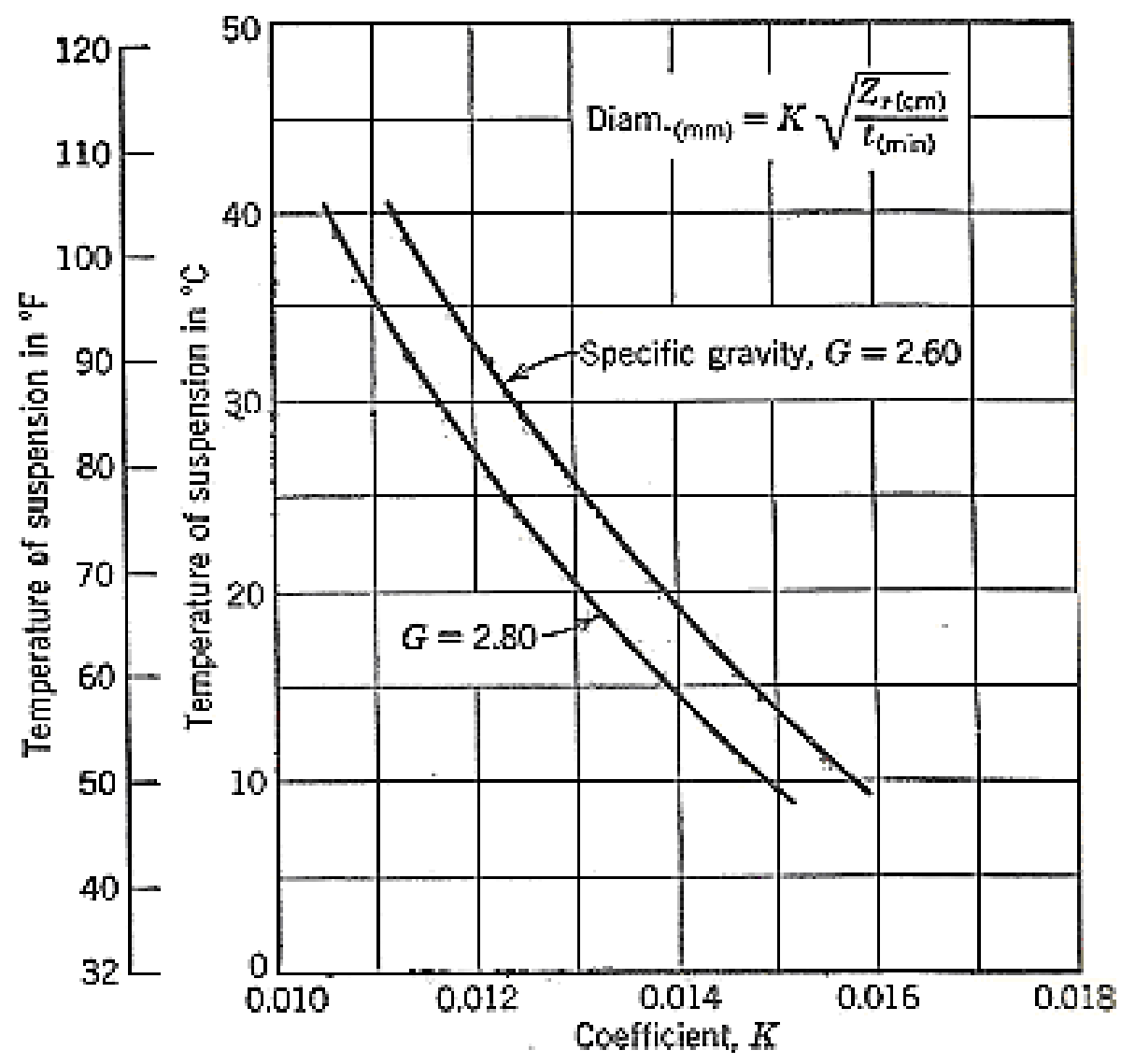

Fig. (2)- Chart for aid in solving stokes equation.(Courtesy of H.P. Aldrich of M.I.T.).After (Lamb, 1951). 

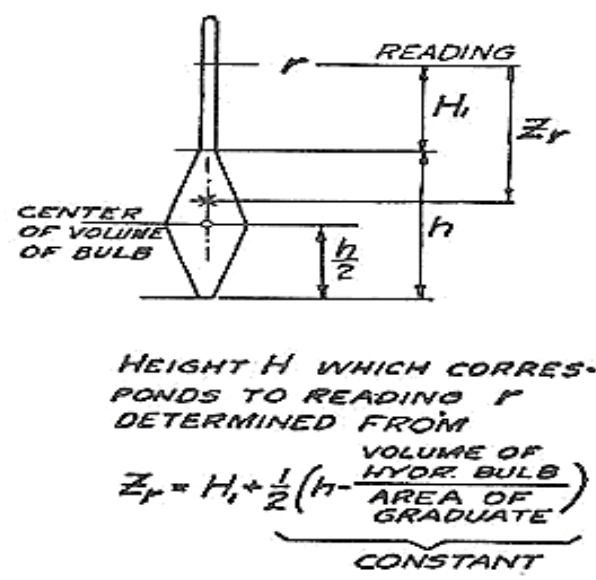

Fig (3): Description of $Z_{r l}$, after (Lamb, 1951).

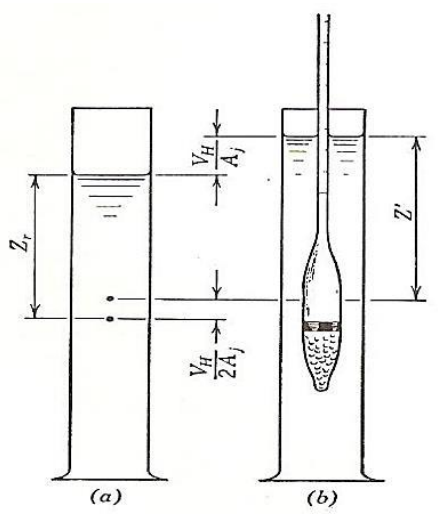

Fig (4): Graduate and hydrometer, after (lamb, 1951).

$r_{\text {final }}=\rho_{\text {soluble }}=\frac{w_{\text {soluble }}}{v_{\text {total }}}$

$w_{\text {soluble }}=\rho_{\text {soluble }} \times v_{\text {total }}$....

In hydrometer test the effect of the deflocculating agent should be taken in mind as follow:

The reading of the hydrometer in cylinder with the deflocculating agent only equal to (1.003) but with the present of soil a lot of this agent settles down with soil 
particle. So the final solution density could be found by using equation (6) as shown by (Van, 2002)

$\rho_{1}=\rho_{\text {water }}\left(1+0.63 \times C_{S}\right)$

Where:

$$
\begin{aligned}
& \rho_{1}=\text { solution density (water }+ \text { dispersing agent) without salts in } \mathrm{g} / \mathrm{cm} 3 \\
& \rho_{\text {water }}=\text { water density in } \mathrm{g} / \mathrm{cm}^{3} \text { at temperature } \mathrm{T} \\
& C_{S}=\text { Concentration dispersing agent in } \mathrm{g} / \mathrm{cm}^{3}
\end{aligned}
$$

In hydrometer test the concentration of the dispersing agent equal to $0.005 \mathrm{~g} / \mathrm{cm}^{3}$

By simplifying equation 7 we get $\rho_{1}=\left(1.00315 \times \rho_{\text {water }}\right)$

$$
w_{1}=\rho_{1} \times v_{\text {total }}
$$

The final hydrometer reading after the constant reading represents the soluble density. So the weight of the solution with the present of salts could be found in equation 9 as bellow:

$w_{\text {soluble }}=(r) \times v_{\text {total }}$

$w_{\text {soluble }}=w_{1}+w_{\text {salt }}$

$w_{\text {salt }}=w_{\text {soluble }}-w_{1}$

$w_{\text {salt }}=\left[\left(r-\rho_{1}\right) \times 1000\right]$

T.D.S. $=\frac{w_{\text {salt }}}{w_{\text {soil }}} \times 100$

And rearranging, the following is obtained:

T.D.S $=\left[\frac{\left(\left(r-\left(1.00315 \times \rho_{\text {water }}\right)\right) \times 1000\right)}{W_{\text {SOIL }}}\right] \times 100$

$\rho_{\text {water }}$ Depending on the soluble temperature and could be taken from Table (2), which taken from international critical, 1928 after (Lamb, 1951).

So the final equation number (14) could be used to find the total dissolved salts in soil.

Where:

$$
\text { E - } 31
$$


T.D.S $=$ Total dissolved salts in soil in $\%$.

$W_{\text {SOIL }}=$ The Weight of the soil used, in gm.

$r=$ final hydrometer reading which could be found from equation(2) or (3) or directly from hydrometer test when the reading be constant that reading refers to salts content.

Table (2):Specific gravity of water - after (Lamb, 1951).

$\begin{array}{ccccccccccc}{ }^{\circ} \mathrm{C} & 0 & 1 & 2 & 3 & 4 & 5 & 6 & 7 & 8 & 9 \\ 0 & 0.9999 & 0.9999 & 1.0000 & 1.0000 & 1.0000 & 1.0000 & 1.0000 & 0.9999 & 0.9999 & 0.9998 \\ 10 & 0.9997 & 0.9996 & 0.9995 & 0.9994 & 0.9993 & 0.9991 & 0.9990 & 0.9988 & 0.9986 & 0.9984 \\ 20 & 0.9982 & 0.9980 & 0.9978 & 0.9976 & 0.9973 & 0.9971 & 0.9968 & 0.9965 & 0.9963 & 0.9900 \\ 30 & 0.9957 & 0.9954 & 0.9951 & 0.9947 & 0.9944 & 0.9941 & 0.9937 & 0.9934 & 0.9930 & 0.9926 \\ 40 & 0.9922 & 0.9919 & 0.9915 & 0.9911 & 0.9907 & 0.9902 & 0.9898 & 0.9894 & 0.9890 & 0.9885 \\ 50 & 0.9881 & 0.9876 & 0.9872 & 0.9867 & 0.9862 & 0.9857 & 0.9852 & 0.9848 & 0.9842 & 0.9838 \\ 60 & 0.9832 & 0.9827 & 0.9822 & 0.9817 & 0.9811 & 0.9806 & 0.9800 & 0.9795 & 0.9789 & 0.9784 \\ 70 & 0.9778 & 0.9772 & 0.9767 & 0.9761 & 0.9755 & 0.9749 & 0.9743 & 0.9737 & 0.9731 & 0.9724 \\ 80 & 0.9718 & 0.9712 & 0.9706 & 0.9699 & 0.9693 & 0.9686 & 0.9680 & 0.9673 & 0.9667 & 0.9660 \\ 90 & 0.9653 & 0.9647 & 0.9640 & 0.9633 & 0.9620 & 0.9619 & 0.9612 & 0.9605 & 0.9598 & 0.9591\end{array}$

* Also the density or unit weight of water in grams per milliliter.

From International Critical Tables, Vol. III, MoGraw-Hill Book Co., 1928.

\section{Samples properties}

The soils used in this study were vastly different in chemical characteristics andthe general soil properties of the soils samples given in Table (3).

\section{Experimental procedure:}

For each sample the following tests are done:

1- Standard hydrometer test according to ASTM standard no.D422

2- The total dissolved salts test as described in(Earth Manual(E2), 1974).

3-the specific gravity test according to ASTM standard no D 854-02. 
مجلة العلوم الهندسية ـ العدد السابع - ديسمبر 2014

Table (3): The Properties andthe Description ofthe Samples.

\begin{tabular}{|c|c|c|c|c|c|c|c|c|c|}
\hline $\begin{array}{l}\text { Sample } \\
\text { no. }\end{array}$ & $\begin{array}{c}\text { Sample } \\
\text { Name }\end{array}$ & Depth & Location & Gs & O.R. & $\mathrm{SO} 3$ & CL- & TDS $\%$ & Soil Description \\
\hline 1 & BH 3 & $2.5-3$ & Diyala & 2.78 & 1.9 & 1.86 & 1050 & 4.84 & $\begin{array}{c}\text { dark brown clayey silt with } \\
\text { some sand }\end{array}$ \\
\hline 2 & $\mathrm{BH} 4$ & $3.5-4.5$ & Diyala & 2.76 & 1.2 & 3.1 & 100 & 8.37 & brown silty clay \\
\hline 3 & BH 1 & $1-1.5$ & Diyala & 2.73 & 1.1 & 2.24 & 180 & 4.82 & $\begin{array}{c}\text { Light brown clayey silt with } \\
\text { gypsum }\end{array}$ \\
\hline 4 & BH 1 & $7.5-9.5$ & Diyala & 2.77 & 1.2 & 4.98 & 225 & 9.98 & light brown silty clay \\
\hline 5 & BH 2 & $9.5-10$ & Diyala & 2.76 & 1.6 & 3.44 & 150 & 8.09 & light brown silty clay \\
\hline 6 & $\mathrm{BH} 2$ & $0-1$ & Diyala & 2.78 & 0.8 & 3.92 & 425 & 8.32 & $\begin{array}{l}\text { dark brown clayey silt and } \\
\text { full } 1 \text { and organic maturia }\end{array}$ \\
\hline 7 & $\mathrm{BH} 3$ & $24-30$ & Holy Karbala & 2.67 & 1.2 & 4.29 & 225 & 11.31 & $\begin{array}{l}\text { yellow to light brown silty } \\
\text { sand with small gravel }\end{array}$ \\
\hline 8 & BH 1 & $19-26$ & Holy Karbala & 2.69 & 1.3 & 3.45 & 75 & 8.41 & $\begin{array}{c}\text { white to yellow sandy silt } \\
\text { with clay, with salts }\end{array}$ \\
\hline 9 & BH 1 & $5.0-9.0$ & Holy Karbala & 2.77 & 1.93 & 8.93 & 250 & 21.13 & $\begin{array}{c}\text { white to yellow sandy silt } \\
\text { with clay, with salts }\end{array}$ \\
\hline 10 & BH 8 & $12.0-16$ & Holy Karbala & 2.68 & 1.1 & 3.32 & 100 & 9.92 & $\begin{array}{l}\text { yellow to light brown silty } \\
\text { sand with small gravel }\end{array}$ \\
\hline 11 & BH 3 & $10.0-14$ & Holy Karbala & 2.69 & 3.43 & 4.06 & 100 & 10.33 & $\begin{array}{l}\text { brown to red silty sand with } \\
\text { clay and salts and organic }\end{array}$ \\
\hline 12 & BH 3 & $18-24$ & Holy Karbala & 2.67 & 0.6 & 2.66 & 100 & 6.72 & $\begin{array}{l}\text { yellow to light brown silty } \\
\text { sand with small gravel }\end{array}$ \\
\hline 13 & BH 7 & $15-18$ & Holy Karbala & 2.77 & 2.1 & 5.03 & 100 & 12.33 & $\begin{array}{c}\text { red to brown clayey silt with } \\
\text { sand and high organic and } \\
\text { gypsum }\end{array}$ \\
\hline 14 & BH 1 & $13-19$ & Holy Karbala & 2.78 & 3.92 & 7.08 & 125 & 17.33 & $\begin{array}{l}\text { red silty clayey sand with } \\
\text { gypsum }\end{array}$ \\
\hline 15 & $\mathrm{BH} 3$ & $7.0-10$ & Holy Karbala & 2.71 & 2.72 & 2.72 & 75 & 7.32 & $\begin{array}{c}\text { white to yellow sandy silt } \\
\text { with clay, with salts }\end{array}$ \\
\hline 16 & BH 1 & $19.5-20$ & Koit & 2.79 & 0.3 & 2.73 & 2075 & 5.71 & $\begin{array}{c}\text { brown clayey sandy silt with } \\
\text { very high organic }\end{array}$ \\
\hline 17 & BH 1 & $0.0-1.5$ & Baghdad & 2.79 & 0.4 & 2.72 & 250 & 8.11 & $\begin{array}{l}\text { silty clay with fill material } \\
\text { and salts }\end{array}$ \\
\hline 18 & BH 3 & $1.5-2$ & Baghdad & 2.74 & 2.1 & 3.11 & - & 7.76 & brown clayey silt \\
\hline 19 & $\mathrm{BH} 2$ & $2.5-4.5$ & Baghdad & 2.75 & 1.1 & 3.81 & 150 & 9.62 & $\begin{array}{c}\text { silty clay with fill material } \\
\text { (broken brick) }\end{array}$ \\
\hline 20 & BH 1 & $8-8.5$ & Baghdad & 2.71 & 2.9 & 4.23 & 600 & 11 & brown to gray clayey silt \\
\hline 21 & BH 1 & $13-13.5$ & Baghdad-kreat & 2.69 & 1.1 & 1.48 & 100 & 3.75 & dark gray clayey silt \\
\hline 22 & BH 2 & $10.5-11$ & Baghdad-kreat & 2.76 & 0.6 & 1.38 & 50 & 3.75 & $\begin{array}{c}\text { dark gray silty clay to clayey } \\
\text { silt }\end{array}$ \\
\hline 23 & BH 1 & $8-8.5$ & Baghdad-al sader & 2.74 & 2.9 & 3.54 & - & 10.5 & $\begin{array}{l}\text { brown silty clay stiff with } \\
\text { broken bricks }\end{array}$ \\
\hline 24 & $\mathrm{BH} 2$ & $7-7.5$ & Baghdad-al sader & 2.75 & 1.8 & 0.91 & - & 4 & brown clay with silt \\
\hline 25 & $\mathrm{BH} 2$ & $2-2.5$ & Baghdad-al sader & 2.69 & 1.3 & 1.37 & - & 3.75 & brown silt with clay \\
\hline 26 & BH 1 & 2. -2.5 & al-kider & 2.74 & 1.9 & 4.01 & - & 11.75 & $\begin{array}{l}\text { brown silty clay to clayey } \\
\text { silt with sand }\end{array}$ \\
\hline 27 & D3 & $2-2.5$ & Baghdad-al jadreah & 2.78 & 0.9 & 1.03 & 600 & 3.11 & brown clayey silt \\
\hline 28 & BH 5 & $3-3.5$ & Badrah & 2.77 & 0.1 & 0.36 & - & 0.75 & brown silty clay \\
\hline 29 & $\mathrm{BH} 7$ & $0.5-1$ & Badrah & 2.76 & 0.3 & 0.47 & - & 0.89 & brown clayey silt \\
\hline 30 & BH 2 & $|10-10.5|$ & Slah el deen & 2.71 & 1.1 & 2.48 & - & 7.93 & $\begin{array}{c}\text { silty coarse and fine sand } \\
\text { with gravel }\end{array}$ \\
\hline
\end{tabular}

E - 33 
Note:

$\rho_{\text {water }}$ Depending on the soluble temperature and could be taken from Table (3), which taken from international critical, 1928 after (Lamb, 1951).
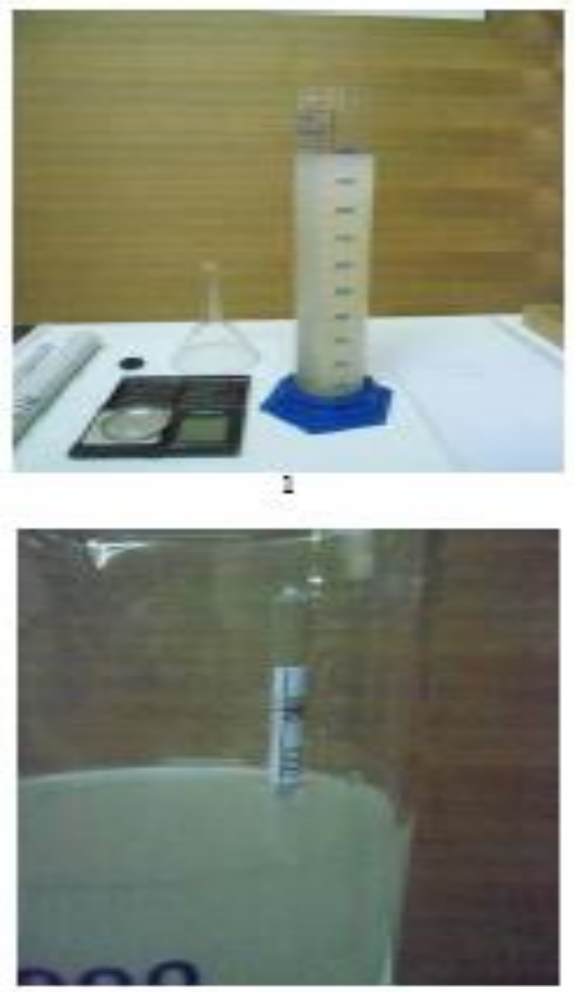

3
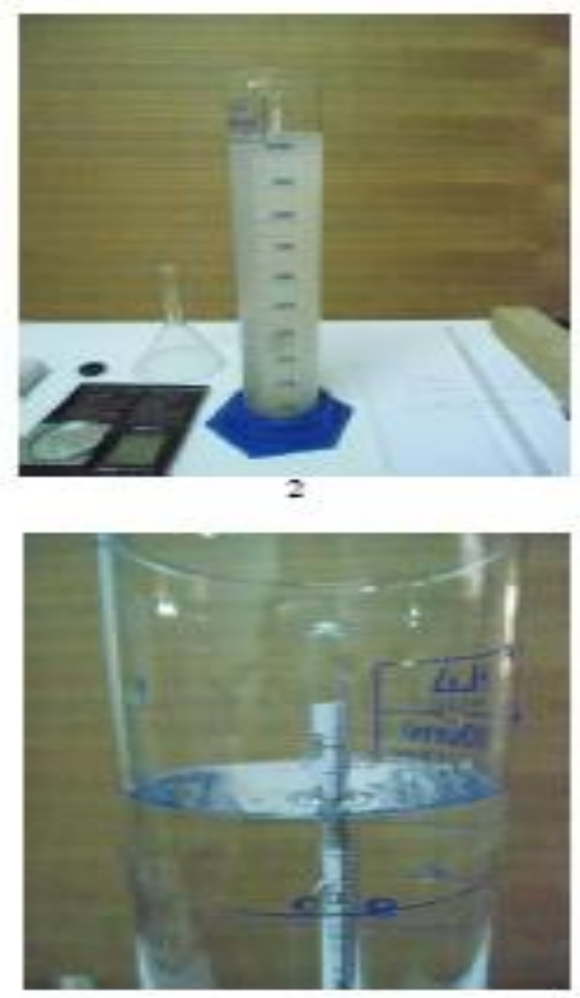

4

Fig. (5): Recommended hydrometer test for the soil samples.

The results of the hydrometer test for all samples shown in figures from 7 to 10 .

These figures represent particle size distribution, in this research the last reading of the hydrometer and the temperature of the soluble are what we need for finding the total dissolved salts. This reading could be found from the particle size distribution curve by applying equation number(3), or could use equation no.(4) If we know all properties of the hydrometer used.

The results what needed are shown in Table (5). 
مجلة العلوم الهندسية ـ العدد السابع - ديسمبر 2014
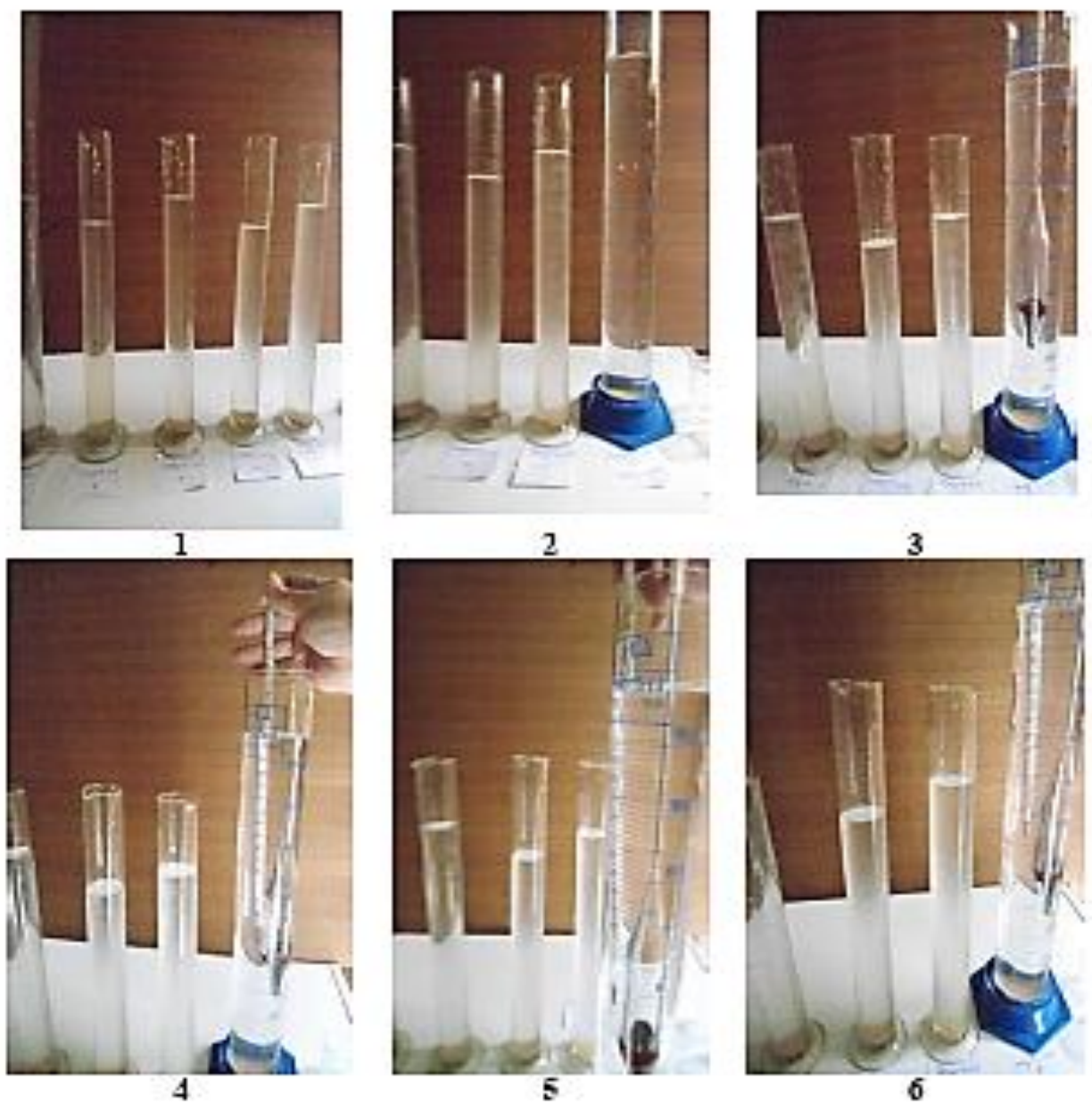

Fig. (6): the combination between the hydrometer test and the proposed TDS test.

Figures (7, 8, 9 and 10) show the particle size distribution curve for the soils samples shown below:

$$
\text { E - } 35
$$




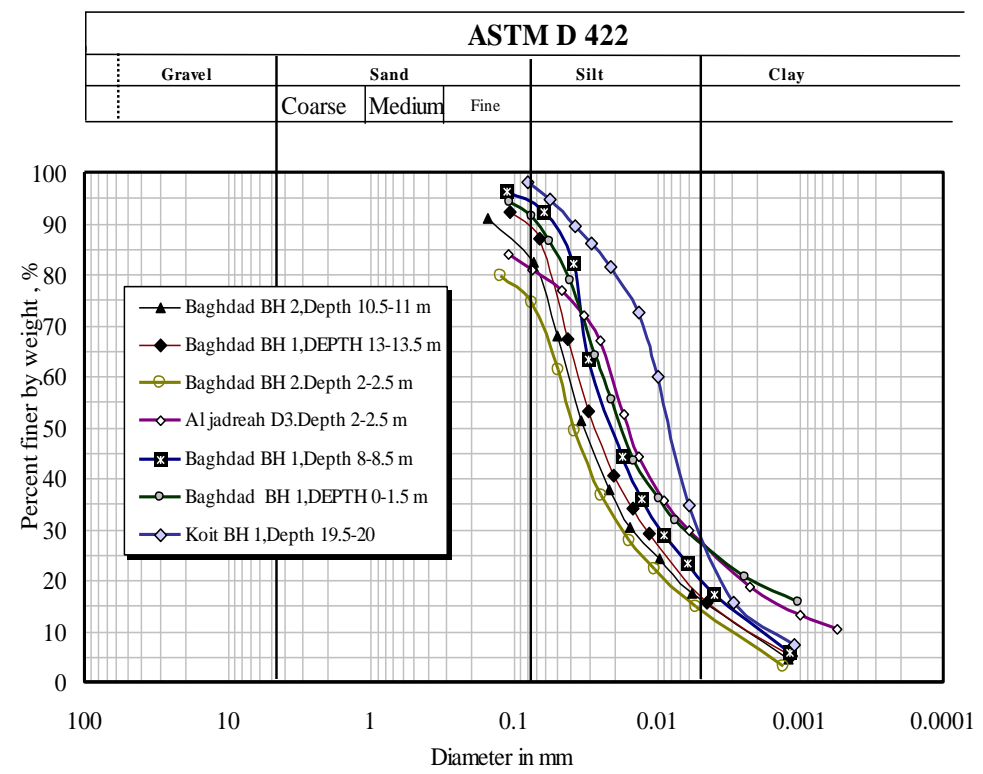

Fig. (7): The particle size distribution curve for the soils samples

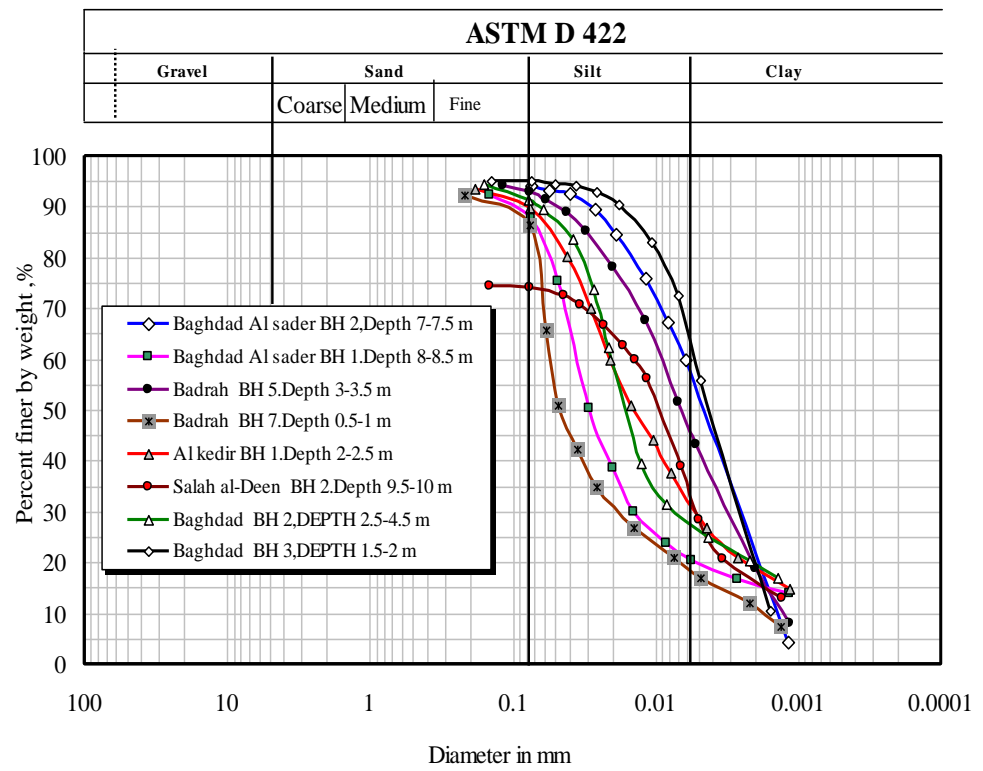

Fig. (8): The particle size distribution curve for the soils samples

E - 36 
مجلة العلوم الهندسية ـ العدد السابع - ديسمبر 2014

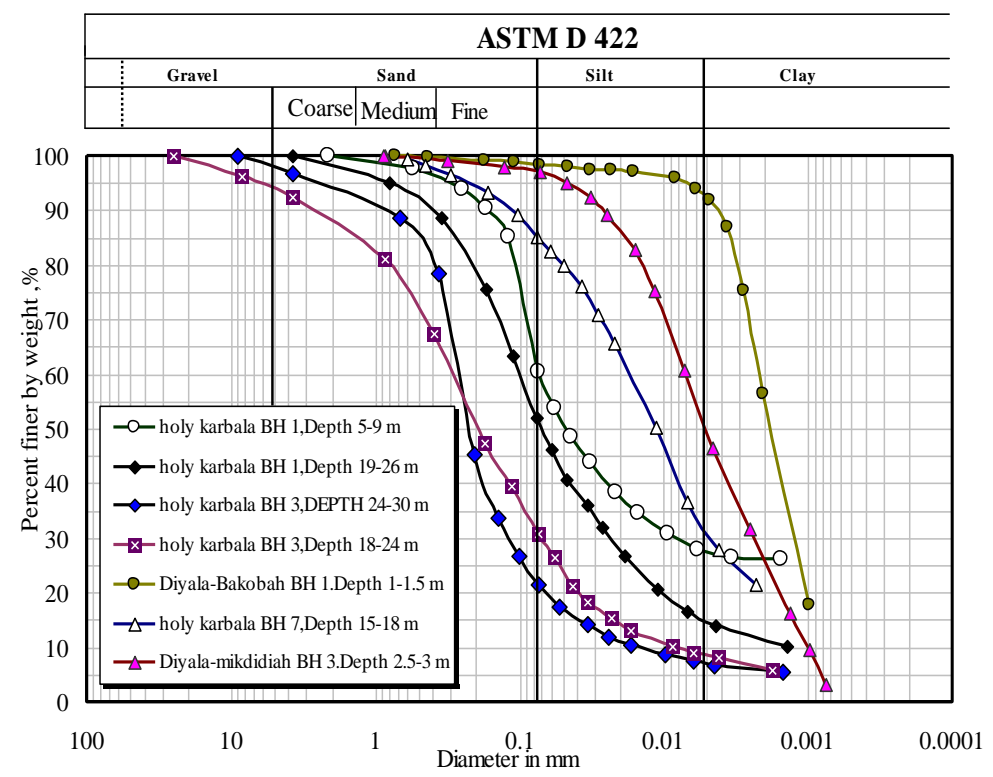

Fig. (9): The particle size distribution curve for the soils samples

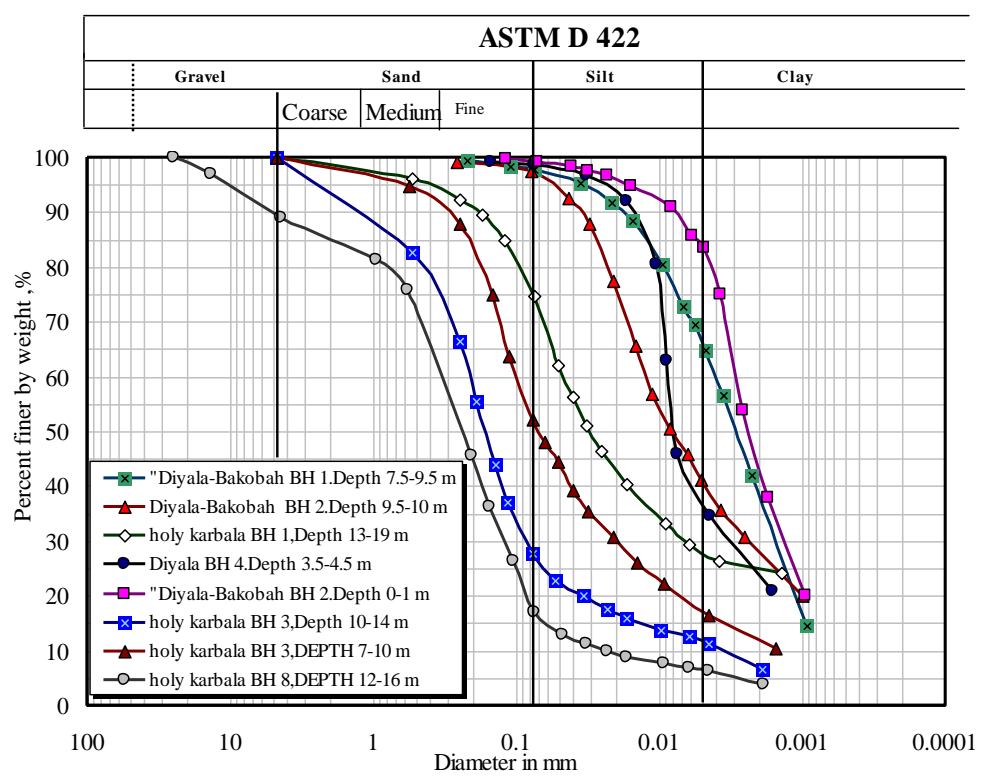

Fig. (10): The particle size distribution curve for the soils samples

E - 37 
The experimental results shown in Table (5) as below:

Table (5): The experimental results

\begin{tabular}{|c|c|c|c|c|c|c|c|c|}
\hline $\begin{array}{l}\text { Sampl } \\
\text { e no. }\end{array}$ & $\begin{array}{c}\text { sample } \\
\text { name }\end{array}$ & depth & location & $\begin{array}{c}\text { TDS by } \\
\text { natural } \\
\text { method \% }\end{array}$ & $\begin{array}{l}\text { r hydrometer } \\
\text { (final reading) }\end{array}$ & $\mathbf{T}$ & $\begin{array}{c}\mathbf{r} \\
\text { water } \\
\text { from } \\
\text { table } 3\end{array}$ & $\begin{array}{l}\text { TDS by } \\
\text { Derived } \\
\text { equation }\end{array}$ \\
\hline 1 & $\mathrm{BH} 3$ & $2.5-3$ & Diyala & 4.84 & 1.001 & 33 & 0.9947 & 6.333 \\
\hline 2 & BH 4 & $3.5-4.5$ & Diyala & 8.37 & 1.00675 & 13 & 0.9994 & 8.404 \\
\hline 3 & $\mathrm{BH} 1$ & $1-1.5$ & Diyala & 4.82 & 1.00575 & 14 & 0.9993 & 6.604 \\
\hline 4 & $\mathrm{BH} 1$ & $7.5-9.5$ & Diyala & 3.97 & 1.00475 & 14 & 0.9993 & 4.604 \\
\hline 5 & $\mathrm{BH} 2$ & $9.5-10$ & Diyala & 8.09 & 1.0065 & 14 & 0.9993 & 8.104 \\
\hline 6 & BH 2 & $0-1$ & Diyala & 8.32 & 1.0065 & 14 & 0.9993 & 8.104 \\
\hline 7 & $\mathrm{BH} 3$ & $24-30$ & Holy Karbala & 11.31 & 1.008 & 16 & 0.9990 & 11.706 \\
\hline 8 & BH 1 & $19-26$ & Holy Karbala & 8.41 & 1.00625 & 16 & 0.9990 & 8.206 \\
\hline 9 & BH 1 & $5.0-9.0$ & Holy Karbala & 21.13 & 1.014 & 16 & 0.9990 & 23.706 \\
\hline 10 & $\mathrm{BH} 8$ & $12.0-16$ & Holy Karbala & 9.92 & 1.007 & 17 & 0.9988 & 10.108 \\
\hline 11 & $\mathrm{BH} 3$ & $10.0-14$ & Holy Karbala & 10.33 & 1.0075 & 16 & 0.9990 & 10.706 \\
\hline 12 & $\mathrm{BH} 3$ & $18-24$ & Holy Karbala & 6.72 & 1.006 & 16 & 0.9990 & 7.706 \\
\hline 13 & $\mathrm{BH} 7$ & $15-18$ & Holy Karbala & 12.33 & 1.008 & 16 & 0.9990 & 11.706 \\
\hline 14 & BH 1 & $13-19$ & Holy Karbala & 17.33 & 1.01025 & 16 & 0.9990 & 16.206 \\
\hline 15 & $\mathrm{BH} 3$ & $7.0-10$ & Holy Karbala & 7.32 & 1.00625 & 16 & 0.9990 & 8.206 \\
\hline 16 & $\mathrm{BH} 1$ & $19.5-20$ & Koit & 5.71 & 1.0025 & 27 & 0.9965 & 5.722 \\
\hline 17 & $\mathrm{BH} 1$ & $0.0-1.5$ & Baghdad & 8.11 & 1.0055 & 21 & 0.9980 & 8.713 \\
\hline 18 & BH 3 & $1.5-2$ & Baghdad & 7.76 & 1.0035 & 29 & 0.9960 & 8.725 \\
\hline 19 & $\mathrm{BH} 2$ & $2.5-4.5$ & Baghdad & 9.62 & 1.006 & 21 & 0.9980 & 9.713 \\
\hline 20 & BH 1 & $8-8.5$ & Baghdad & 11 & 1.002 & 38 & 0.9930 & 11.744 \\
\hline 21 & BH 1 & $13-13.5$ & Baghdad-kreat & 3.75 & 1.00175 & 27 & 0.9965 & 4.222 \\
\hline 22 & $\mathrm{BH} 2$ & $10.5-11$ & Baghdad-kreat & 3.75 & 1.00175 & 27 & 0.9965 & 4.222 \\
\hline 23 & $\mathrm{BH} 1$ & $8-8.5$ & Baghdad-al sader & 10.5 & 1.005 & 29 & 0.9960 & 11.725 \\
\hline 24 & BH2 & $7-7.5$ & Baghdad-al sader & 4 & 1.0015 & 29 & 0.9960 & 4.725 \\
\hline 25 & BH 2 & $2-2.5$ & Baghdad-al sader & 3.75 & 1.00125 & 29 & 0.9960 & 4.225 \\
\hline 26 & BH 1 & 2. -2.5 & al-kider & 11.75 & 1.00525 & 30 & 0.9957 & 12.827 \\
\hline 27 & D3 & $2-2.5$ & Baghdad-al jadreah & 3.11 & 1.004 & 16 & 0.9990 & 3.706 \\
\hline 28 & BH 5 & $3-3.5$ & Badrah & 0.75 & 1.00275 & 15 & 0.9991 & 1.006 \\
\hline 29 & $\mathrm{BH} 7$ & $0.5-1$ & Badrah & 0.89 & 1.00275 & 15 & 0.9991 & 1.006 \\
\hline 30 & BH 2 & $10-10.5$ & Slah el deen & 7.93 & 1.0055 & 20 & 0.9982 & 8.311 \\
\hline
\end{tabular}

E - 38 
The total dissolved salts could be found by applying the derived equation (14) in the last column in Table (5) these results are shown.

These results drown in Figure (11) to find the compatibility between the actual and estimated total dissolved salts.

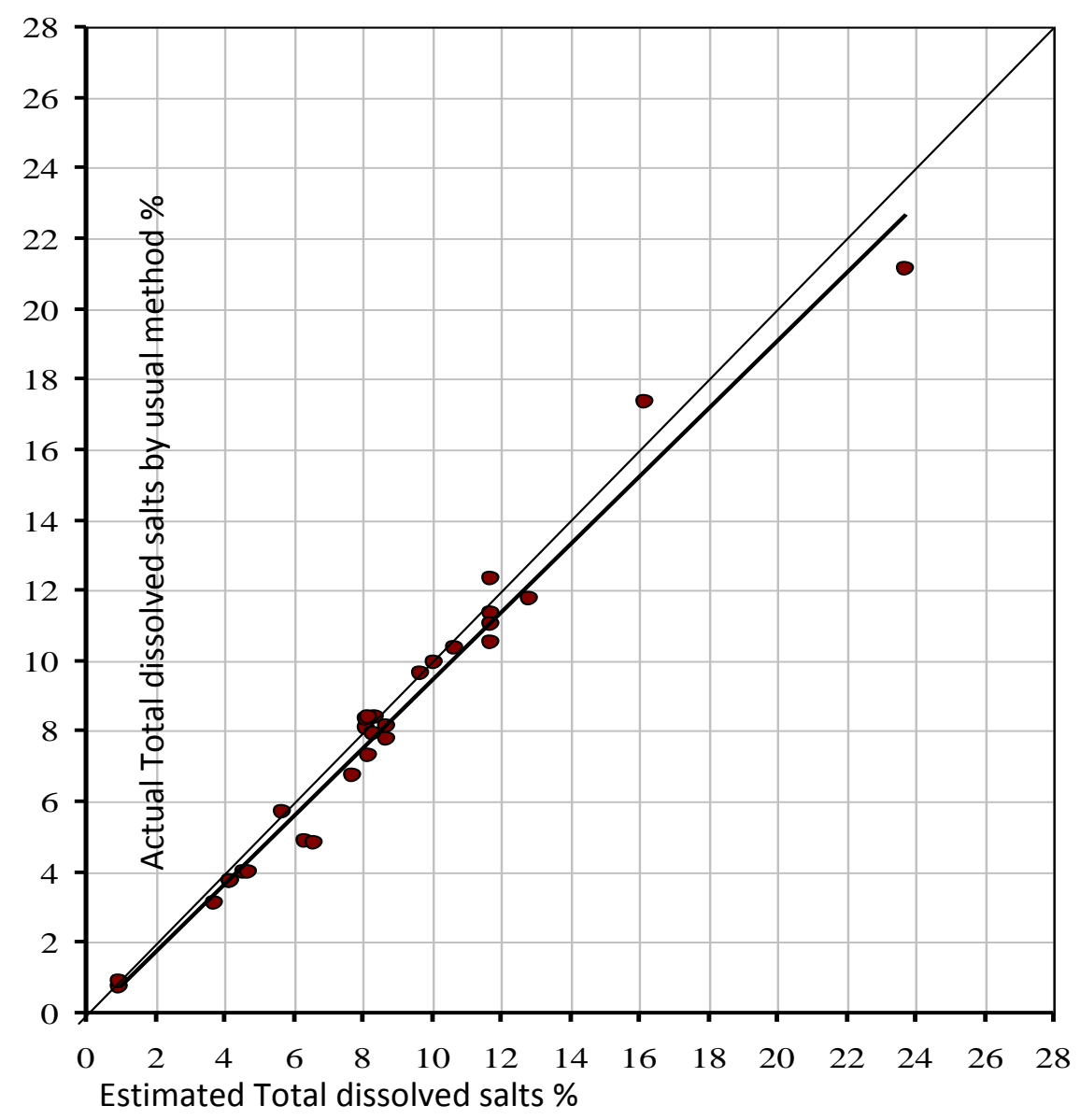

Fig. (11): The Relation between the Estimated Total Salts and the Actual Dissolved Salts.

Figure (11) show that the derived equation get a very good results were the correlation factor equal to $(0.988)$ and the $\left(\mathrm{R}^{2}\right)$ equal to $(0.9755)$. 


\section{Conclusions:}

1- This research prepared to submit the equation to find the total dissolved salts but form the hydrometer test which usually used to find the particle size distribution curve. The equation underneath could be apply to find the total dissolved salts.

$$
\text { T.D.S }=\left[\frac{\left(\left(r-\left(1.00315 \times \rho_{\text {water }}\right)\right) \times 1000\right)}{W_{\text {SOIL }}}\right] \times 100
$$

Where

$r=$ the final hydrometer reading, when the reading be constant.

2-The proposed method is a rapid and reasonably precise determination that does not alter or consume the samples.

3-The results which found by the derived equation give a very good compatibility with that found by the ordinary method. The root square equal (0.9755) and correlation factor equal (0.988).

\section{References:}

[1] Akridge, D., 2008. Methods for calculating brine evaporation rates during salt production. Journal of Archaeological Science 35, 1453-1462.

[2] Al-Amoudi, O. and Abduljauwad, S. 1995. Compressibility and CollapseCharacteristics of Arid Saline Sabkha Soils, Engineering Geology, 39(3-4): 185-202.

[3] Amoudi, O. 2001. Characterization and Chemical Stabilization of AlQurayyahSabkha Soil, Journal of Materials in Civil Engineering, 14(6): 478484.

[4] Anderson, M. S., Keyes, Mary Get and Cromer, George W., 1942," Soluble material of soils in relation to their classification and general fertility", USDA Tech. Bull. 813. U. S. Govt. Printing Office, Washington. 79 pp.

[5] ASTM Standard D854-02 Standard test methods for specific gravity of soil solids by water pycnometer ${ }^{1}$.

[6] ASTM Standard, D422Test Method for Particle-Size Analysis of Soils.

[7] Bashour I. and Sayegh A., Methods of Analysis for Soils of Arid and SemiArid Regions,American University of Beirut,Beirut, Lebanon,2007.

$$
\text { E - } 40
$$


[8] Bilsel, H. 2004. Hydraulic Properties of Soils Derived from Marine Sediments of Cyprus, Journal of Arid Environments, 56(1): 27-41.

[9] Bouyoucos G.J. 1962. Hydrometer method improved for making particle size analysis of soil. Agron. J., 54:464-465.

[10] Casagrande A.,"The hydrometer method for mechanical analysis of soil and other granular materials", Cambridge, Mass., June, 1931.

[11] Chapman, H.O. and Kelley, W.P., 1930, "The determination of the replaceable bases and the base-exchange capacity of soils", Soil Science 30; 391-406.

[12] Earth manual, 1974,"soluble salts", second edition, Washington.

[13] El-Swaify, S.A., S.S. Arunin, and I.P. Abrol. 1983," Soil salinization: development of salt-affected soils. In: Natural systems for development: what planners need to know", MacMillan, NY. Chap. 4, p. 162-228.

[14] El-Swaify, S., 2000, Soil and Water Salinity. From: Plant Nutrient Management in Hawaii's Soils, Approaches for Tropical and Subtropical Agriculture J. A. Silva and R. Uchida, eds. College of Tropical Agriculture and Human Resources, University of Hawaii at Manoa, (02000.

[15] Gualbert, 2001, Density Dependent Groundwater Flow, Salt Water Intrusion and Heat Transport. Utrecht University, Interfaculty Centre of Hydrology Utrecht, Institute of Earth Sciences,Department of Geophysics.

[16] Hofmann, Ulrich,"recent advances in the chemistry of clay", die chemie, Vol.55,no.37/38, September, 1942.

[17] Howard S.1981. THE PORTALAB MANUAL: Low-Cost Soil-Engineering Tests for Constructing Earthen Buildings. New Mexico Energy \& Minerals Department.

[18] International critical tables,McGraw-Hill Book Co.,Vol.ш, 1928.

[19] Kenneth L. D., 1967, "Effect of $\mathrm{CO}_{2}$ onThe Chemical Equilibrium Of Soil Solution And Ground Water", published Ph.D. Thesis, Arizona University.

[20] Kue-Young Kim, Chul-Min Chon and Ki-Hwa Park2, 2007. "A Simple Method for Locating the Fresh Water-Salt Water Interface using Pressure Data", Vol. 45, No. 6- Ground Water-November-December(p.p. 723-728). 
[21] Lambe, T.W. 1951. Soil Testing for Engineers, John Wiley and Sons, New York.

[22] Mitchell, J.K., and Soga, K.(2005) Fundamentals of soil behavior, Third edition, John Wiley and Sons, Inc., ISBN 978-0-471-46302-7.

[23] Osama K., Ahmed A. Al-Mufty and Rasheed A.2008. Determination of Saline Soils Specific Gravity, Jordan Journal of Civil Engineering, Volume 2, No. 1.

[24] Reitemeier, R.F. 1946,"Effect of moisture content on the dissolved and exchangeable ions of soils of arid regions", Soil Sci. 61: 195-214.

[25] Romanklw, L.A., Chou, I.-M., 1983. Densities of aqueous $\mathrm{NaCl}, \mathrm{KCl}, \mathrm{MgCl} 2$, and $\mathrm{CaCl} 2$ binary solutions in the concentration range $0.5-6.1 \mathrm{~m}$ at $25,30,35$, 40, and $45^{\circ} \mathrm{C}$. Journal of Chemical and Engineering Data 28, 300, 305.

[26] Rongzhen, D., Baoguo, M., Xingyang, H. and Hongbo, Z. 2006. Sulfate Attack on Concrete in an Inland Salt Lake Environment, Journal of China University of Geosciences, 17(4): 342-248.

[27] Standard Specification for Urban Infrastructure Works, Edition 1, Revision 0/ September 2002.

[28] Stuyfzand, P.J. 1989,"An accurate relatively simple calculation of the saturation index of calcite for fresh to salt water", Journal of Hydrology 105, no. 1-2: 95-107.

[29] United States Salinity Laboratory Staff. 1954. "Diagnosis and improvement of saline and alkali soils". USDA Agr. Handbook, No. 60, U. S. Govt. Printing Office, Washington.160 p.

[30] Van R.L., 2002, Procedures for Soil Analysis, Wageningen: International Soil Reference and Information Center. ISSN 0923-3792:NO.9

[31] Weast, R.C., Editor. 1974, "Handbook of Chemistry and Physics", 55th ed., Chemical Rubber Co., CRC Press, Ohio, USA.

[32] Zhou Y., 2006. Soil Mechanics: Stress and Strain, U.S. Department of Transportation, Publication No. FHWA NHI-06-088 Federal Highway Administration December 2006. 


\section{Sample used:}

T.D.S $=$ Total dissolved salts in $\%$

$W_{\text {SOIL }}=$ The weight of the soil used, in gm.

$r=$ Final hydrometer reading which could be found from equation(3) or (4) or directly from hydrometer test when the reading be constant that reading refers to salts content.

$\rho_{1}=$ Solution density (water + dispersing agent) without salts in $\mathrm{g} / \mathrm{cm} 3$

$\rho_{\text {water }}=$ Water density in $\mathrm{g} / \mathrm{cm}^{3}$ at temperature $\mathrm{T}$

$C_{S}=$ Concentration dispersing agent in $\mathrm{g} / \mathrm{cm}^{3}$

$\rho=\operatorname{Density}\left(\mathrm{kg} / \mathrm{m}^{3}\right)$,

$p=\operatorname{Pressure}\left(M L^{-1} T^{-2}\right)$,

$T=$ Temperature $\left(C^{\circ}\right)$,

$S=$ Salinity 1 or total dissolved solids(TDS) $(m g / l)$.

$V_{c y l i n d e r}=1000 \mathrm{~cm}^{3}$

$w_{\text {soilin used } \text { ydrometer }}=50 \mathrm{gm}$

$\gamma_{w @ 20^{\circ} \mathrm{c}=}=0.9982 \mathrm{gm} / \mathrm{cm}^{3}$ 